\title{
KRT10 wt Allele
}

National Cancer Institute

\section{Source}

National Cancer Institute. KRT10 wt Allele. NCI Thesaurus. Code C112152.

Human KRT 10 wild-type allele is located in the vicinity of $17 q 21$ and is approximately $4 \mathrm{~kb}$ in length. This allele, which encodes keratin, type I cytoskeletal 10 protein, is involved in the intermediate filament structure of terminally differentiated epidermal cells. Mutations in this gene are associated with epidermolytic hyperkeratosis, ichthyosis with confetti, and cyclic ichthyosis with epidermolytic hyperkeratosis. 